\title{
Liver protein expression in dairy cows with high liver triglycerides in early lactation
}

\author{
H. Sejersen, M. T. Sørensen, T. Larsen, E. Bendixen, and K. L. Ingvartsen ${ }^{1}$ \\ Department of Animal Science, Aarhus University, AU Foulum, Blichers Allé 20, PO Box 50, DK-8830 Tjele, Denmark
}

\begin{abstract}
Fatty liver is a frequent subclinical health disorder in dairy cows that may lead to disorders related to the liver function. However, the effect of triglyceride (TG) accumulation on liver metabolic pathways is still unclear. The objective was, therefore, to characterize quantitative differences in the liver proteome between early lactation dairy cows with a low or high liver TG content. The liver proteome analysis indicated that a high liver TG content in early lactation dairy cows is associated with increased oxidation of saturated fatty acids, oxidative stress, and urea synthesis and decreased oxidation of unsaturated fatty acids. Furthermore, liver gluconeogenesis is apparently not impaired by an increased liver TG content. Based on correlations between liver proteins and plasma components, we suggest that future studies investigate the sensitivity and specificity of plasma aspartate aminotransferase, $\beta$-hydroxybutyrate, total bilirubin, total bile acids, and $\gamma$-glutamyltransferase for potential use as blood-based biomarkers for early detection of fatty liver in dairy cows. Our study is the first to study the proteome of dairy cows with naturally occurring fatty liver in early lactation.
\end{abstract}

Key words: proteomics, fatty liver, biomarker, dairy cow

\section{INTRODUCTION}

Fatty liver is a frequent subclinical health disorder in early lactation dairy cows affecting up to $50 \%$ of the dairy cows in this period (Reid, 1980; Ingvartsen, 2006). The development of fatty liver is characterized by an excessive accumulation of lipids in the liver, particularly triglycerides (TG; Bobe et al., 2004). Several risk factors have been suggested, including high BCS caused by prolonged lactation due to reproductive failure and overfeeding in late lactation and the dry period, high

Received June 6, 2011.

Accepted December 22, 2011.

${ }^{1}$ Corresponding author: kli@agrsci.dk rate of body lipid mobilization around calving, low feed intake, and low protein content in the diet (Ingvartsen, 2006). However, fatty liver is a poorly studied disease mainly due to the lack of noninvasive methods for examination of liver lipid content.

High-producing dairy cows usually experience severe negative energy balance during early lactation as a consequence of an insufficient energy intake to meet the energy requirements for milk production (Ingvartsen and Andersen, 2000; Hammon et al., 2009). The deficit between energy consumed and energy expended is primarily covered by mobilization of FA from adipose tissue, resulting in increased concentrations of NEFA in plasma. Although many peripheral tissues remove NEFA from the blood (e.g., the mammary gland), up to $25 \%$ of NEFA are removed by the liver and subsequently oxidized or converted into TG for export as very low density lipoproteins (VLDL; Bergman, 1971; Reid et al., 1979; Boden, 1998; Andersen et al., 2002; Katoh, 2002). The ability of the ruminant liver to secrete TG as part of the VLDL is limited, however, leading to a propensity to accumulate liver TG (Emery et al., 1992; Drackley, 1999).

Although fatty liver may lead to disorders related to liver metabolism, the effect of liver TG accumulation on metabolic pathways such as fatty acid oxidation, urea synthesis, and gluconeogenesis is still unclear (Drackley, 1999). Proteome analysis of liver samples may indicate such changes in liver metabolism at the protein level (Aebersold and Mann, 2003), but this has not yet been studied in early lactation cows with naturally occurring fatty liver (Kuhla et al., 2009). The objective of the present study was, therefore, to characterize quantitative differences in the liver proteome between early lactation dairy cows with a low or high liver TG content.

\section{MATERIALS AND METHODS}

All procedures involving animals were evaluated and approved by the Danish Animal Experiments Inspectorate and complied with the Danish Laws concerning animal experimentation and care of experimental animals. 


\section{Animals}

From a total of 20 multiparous Danish Holstein dairy cows, 4 cows with low $(\mathbf{L})$ and 4 cows with high $(\mathbf{H})$ liver TG at wk 1 postpartum were selected. Among the total of 20 dairy cows, the selected cows in the L and $\mathrm{H}$ groups had the lowest or highest amount of liver TG at wk 1 postpartum, respectively. Liver TG (means \pm $\mathrm{SD}$ ) in the $\mathrm{L}$ and $\mathrm{H}$ groups at wk 1 postpartum was 81 \pm 22 and $234 \pm 81 \mu \mathrm{mol} / \mathrm{g}$ wet weight, respectively. No clinical cases of mastitis or other illnesses existed among the 8 cows.

\section{Feed Intake, BW, and Milk Production}

The cows had ad libitum access to water and feed from -20 to 8 wk relative to calving. Dry matter intake, BW, and milk yield were measured daily and averaged on a weekly basis. The net energy (NE) intake was calculated using composition table values. Proportional milk samples were obtained twice weekly at the afternoon milking during the first 6 wk after calving and stored at $5^{\circ} \mathrm{C}$. Analyses for milk fat, protein, lactose, urea, and SCC were performed within a week of sample collection at a commercial laboratory (Eurofins, Holstebro, Denmark). Energy-corrected milk yield was calculated based on milk yield and composition.

\section{Blood and Liver Sampling}

Blood and liver samples were taken from all 20 dairy cows. Weekly blood samples were obtained in the early afternoon $(\sim 1300 \mathrm{~h})$ from -5 to 6 wk relative to calving. Blood was collected into heparin-containing Vacutainer tubes (Becton, Dickinson and Company, Franklin Lakes, NJ) by puncture of the tail vein. The blood was centrifuged within $1 \mathrm{~h}$ of collection at 2,000 $\times \mathrm{g}$ and $4^{\circ} \mathrm{C}$ for $20 \mathrm{~min}$. The plasma was subsequently stored at $-20^{\circ} \mathrm{C}$. Liver samples were obtained in $-5,1,4$, and 6 wk relative to calving. Liver biopsies were collected through an incision on the right side of the cow between the tenth and eleventh intercostal space on a line from mid-humerus to tuber coxae. An area $(5 \times 5 \mathrm{~cm})$ was shaved and disinfected before a local anesthetic $(5 \mathrm{~mL}$ of $2 \%$ procaine hydrochloride) was injected at the site of incision. After a minimum of $10 \mathrm{~min}$, a $0.5-\mathrm{cm}$ incision was made through the skin. Multiple liver biopsies $(12 \times$ approximately 25 -mg samples $)$ were taken from the incision site using a Manan Automatic Biopsy System (14 gauge $\times 17 \mathrm{~mm}$ notch; Marmon/MD Tech, Gainesville, FL). The multiple liver biopsies were frozen separately (25 mg, on average) immediately after collection in liquid nitrogen and stored at $-80^{\circ} \mathrm{C}$. The incision area was closed using the Auto Suture Royal 35W Stapler (United States Surgical Corp., Norwalk, CT).

\section{Liver and Blood Analyses}

Two liver biopsies $(2 \times$ approximately 25 -mg samples $)$ from each cow were placed in 2 separate tubes. Tube 1 was filled with $0.8 \mathrm{~mL}$ of PBS (pH 7.4) and tube 2 with $0.33 \mathrm{~mL}$ of chloroform and $0.67 \mathrm{~mL}$ of methanol, whereupon the liver tissue in both tubes was homogenized using a TissueLyser (Qiagen Retsch, Haan, Germany). Triton X-100 (0.2 mL of 5\% stock) was added to tube 1 after homogenization. The supernatants were collected after centrifugation at $2,000 \times g$ and $20^{\circ} \mathrm{C}$ for $15 \mathrm{~min}$. The supernatant of tube 1 was mixed thoroughly and divided into 2 tubes (A and $\mathrm{B}$ ). Tube $\mathrm{A}$ was stored at $-20^{\circ} \mathrm{C}$ and subsequently used for free glucose analysis, whereas tube B was used for glycogen analysis as described previously (Andersen et al., 2002). The supernatant of tube 2 was filled with $1 \mathrm{~mL}$ of chloroform and $0.5 \mathrm{~mL}$ of salt water $\left(0.04 \% \mathrm{CaCl}_{2}, 0.034 \% \mathrm{MgCl}_{2}\right.$, and $0.58 \% \mathrm{NaCl}$ ), and centrifuged at $2,000 \times g$ and $20^{\circ} \mathrm{C}$ for $15 \mathrm{~min}$. The resulting upper phase was removed with a pipette and $0.25 \mathrm{~mL}$ methanol added to the lower phase. The lipid extract was dried under constant $\mathrm{N}_{2}$ airflow at $50^{\circ} \mathrm{C}$ for 30 min using a ZipVap Evaporator (Glas-Col LLC, Terre Haute, IN) and saponified in $\mathrm{KOH}$-ethanol $\left(1.2 \mathrm{~mL}\right.$ of $0.5 \mathrm{M}$ stock) at $60^{\circ} \mathrm{C}$ for $30 \mathrm{~min}$. The hydrolyzed extract was neutralized with $\mathrm{MgSO}_{4}(2.8 \mathrm{~mL}$ of $0.15 \mathrm{M}$ stock$)$ and used for analysis of phospholipids (PL) and TG.

The concentrations of TG, total cholesterol, glucose, protein, urea, calcium, and total bilirubin (TBIL), and the enzyme activities of plasma aspartate aminotransferase (AST), $\gamma$-glutamyltransferase (GGT), and alkaline phosphatase (AP) were measured according to standard procedures (Siemens Diagnostics, Tarrytown, NY). The enzyme activity of plasma glutamate dehydrogenase was measured as described by Schmidt and Schmidt (1995). The concentrations of NEFA and choline-containing PL were measured using the commercially available kits, NEFA C and Phospholipid C, respectively (Wako Chemicals Inc., Richmond, VA). The concentration of total bile acids (TBA) was measured using a commercially available kit (Randox Laboratories Ltd., Crumlin, UK). The concentration of BHBA was measured as described previously (Harano et al., 1985; Mashek et al., 2001). The blood and liver analyses were performed using the ADVIA 1650 Chemistry System (Siemens Medical Solutions, Tarrytown, NY). The intra- and interassay coefficients of variation were all below $4 \%$ for the above-mentioned metabolites and enzymes. 


\section{Proteome Analyses}

Protein Extraction, Tryptic Digestion, and Isobaric Tags for Relative and Absolute Quantification Labeling. The liver samples from wk 1 postpartum were used for the proteome analysis. Four liver biopsies $(4 \times$ approximately 25 -mg samples $)$ from each cow were homogenized in N-Tris(hydroxymethyl) methyl-2-aminoethanesulfonic acid (TES) buffer [10 mM Tris-HCl (pH 7.6), $1 \mathrm{mM}$ EDTA, and 0.25 $M$ sucrose] using a TissueLyser (Qiagen Retsch) and the homogenate centrifuged at $10,000 \times g$ and $4^{\circ} \mathrm{C}$ for $30 \mathrm{~min}$. The protein content of the supernatant was determined using the BCA Protein Assay Kit (Pierce Biotechnology Inc., Rockford, IL) and stored at $-80^{\circ} \mathrm{C}$. An aliquot of $100 \mu \mathrm{g}$ of protein from each sample was finally extracted from the supernatant by precipitation in ice-cold acetone.

The precipitated protein pellets were subjected to denaturation, cysteine reduction/blocking, tryptic digestion, and peptide isobaric tags for relative and absolute quantification (iTRAQ) labeling using reagents from the iTRAQ Reagent Multi-Plex Kit according to the manufacturer's instructions (Applied Biosystems Inc., Foster City, CA). The proteins were digested with trypsin $(10 \mu \mathrm{L}$ of $1 \mu \mathrm{g} / \mu \mathrm{L}$ stock $)$ at $37^{\circ} \mathrm{C}$ overnight (Applied Biosystems Inc.). The tryptic digests were centrifuged the next day at $10,000 \times g$ for 10 min using VectaSpin microtube filters (Whatman International Ltd., Maidstone, UK) and the samples dried and stored at $-80^{\circ} \mathrm{C}$ after labeling.

A total of 4 iTRAQ sets were prepared using a common reference design. Each iTRAQ set contained 3 liver samples, namely 2 individual animal samples from the $\mathrm{L}$ and $\mathrm{H}$ groups, respectively, and a reference sample. The reference sample was made from a pool of liver tissue from 12 randomly selected cows from 1 to 6 wk relative to calving. The reference sample is being used in other bovine liver studies in our laboratory and will allow the present data to be compared with future bovine liver studies.

Strong Cation Exchange Fractionation. The iTRAQ-labeled samples were dissolved in running buffer $(0.03 \%$ formic acid and $5 \%$ acetonitrile in water). An amount of $50 \mu \mathrm{g}$ protein digest was loaded into a capillary HPLC system equipped with a Zorbax Bio-strong cation exchange (SCX) II column (Agilent Technologies Inc., Palo Alto, CA). Peptide elution was performed with a gradient increase in $\mathrm{NaCl}$ concentration $(0 \mathrm{~min}, 0 \% \mathrm{~B} ; 4 \mathrm{~min}, 0 \% \mathrm{~B} ; 10 \mathrm{~min}, 8 \% \mathrm{~B} ; 20 \mathrm{~min}$, $15 \% \mathrm{~B} ; 35.5 \mathrm{~min}, 50 \% \mathrm{~B} ; 45.5 \mathrm{~min}, 100 \% \mathrm{~B}$; and 65.5 min, $100 \% \mathrm{~B})$. The elution buffer B $(0.03 \%$ formic acid, $5 \%$ acetonitrile, and $1 \mathrm{M} \mathrm{NaCl}$ ) was prepared in water. The flow rate was $15 \mu \mathrm{L} / \mathrm{min}$ and 1 -min fractions were collected for 65.5 min and subsequently pooled into 10 samples.

Liquid Chromatography-Tandem Mass Spectrometry. The pooled SCX samples were loaded (at 20 $\mu \mathrm{L} / \mathrm{min}$ ) into a nano reverse-phase (RP)-HPLC system equipped with a Zorbax 300SB C18 guard column and a Zorbax 300SB C18 analytical column (Agilent Technologies Inc.). The guard column output capillary was switched into the path of the analytical column after 10 min. Peptide elution was performed with a gradient increase in acetonitrile concentration $(0 \mathrm{~min}, 0 \% \mathrm{~B} ; 7$ min, 5\% B; $70 \mathrm{~min}, 40 \%$ B; $73 \mathrm{~min}, 95 \%$ B; $78 \mathrm{~min}$, $95 \% \mathrm{~B} ; 83 \mathrm{~min}, 5 \% \mathrm{~B}$; and $100 \mathrm{~min}, 5 \% \mathrm{~B})$. The running buffer $(0.1 \%$ formic acid) and elution buffer B $(0.1 \%$ formic acid and $94.9 \%$ acetonitrile) were prepared in water. The flow rate was $0.3 \mu \mathrm{L} / \mathrm{min}$ and peptides were eluted directly into the Q-star Elite mass spectrometer (Applied Biosystems Inc.), which was equipped with a nanospray ion source using an uncoated $10-\mu \mathrm{m}$ inner diameter SilicaTip PicoTip nanospray emitter (New Objective Inc., Woburn, MA).

Protein Detection and Quantification. Each iTRAQ-labeled sample was injected and analyzed twice on liquid chromatography-tandem mass spectrometry to gain greater proteome coverage. The data were processed and searched against a protein targetdatabase with the ProteinPilot 1.0 software (Applied Biosystems Inc.). The target database contained 39,746 sequences in total and included reversed target sequences (decoy) and common contaminant sequences. The target sequences of Bos taurus originated from the UniProtKB database (http://www.uniprot.org/unipr ot/?query=organism\%3a9913+keyword\%3a1185\&for mat=*; updated February 25, 2009). Mass tolerances of $0.15 \mathrm{Da}$ for peptides and 0.1 Da for fragments as well as 1 missed tryptic cleavage were allowed. Protein detections were accepted when the ProtScore (in the ProteinPilot software) was $\geq 1.3$ (equivalent to $95 \%$ confidence). The search engine included the generic set of AA modifications of the Paragon algorithm, which most importantly includes variable deamidation of asparagine and glutamine side chains, and oxidation of methionine. Methylmethanethiosulfate-labeled cysteines and iTRAQ labeling of lysines and N-termini were regarded as fixed modifications in the search process.

\section{Statistical Analyses}

All data except proteome data were subjected to repeated measures ANOVA using a mixed model with the effect of cow as random. The fixed variables were liver TG group ( $\mathrm{L}$ or $\mathrm{H})$, week relative to calving, and the associated interaction. The pre- and postpartum periods were analyzed separately. All analyses were 
Table 1. Dry matter intake, net energy intake, BW, and milk production in cows selected for low (L) or high (H) liver triglycerides (TG) at wk 1 postpartum

\begin{tabular}{|c|c|c|c|c|c|}
\hline \multirow[b]{2}{*}{ Variable } & \multicolumn{2}{|c|}{ Liver TG $(1-T G)^{1}$} & \multicolumn{3}{|c|}{$P$-value } \\
\hline & $\mathrm{L}$ & $\mathrm{H}$ & l-TG & Week & l-TG $\times$ week \\
\hline Postpartum & $18.5 \pm 1.3$ & $14.7 \pm 1.3$ & 0.09 & $<0.01$ & 0.84 \\
\hline \multicolumn{6}{|l|}{$\mathrm{NE}_{\text {intake }}^{2}(\mathrm{MJ} / \mathrm{d})$} \\
\hline Prepartum & $36.2 \pm 9.7$ & $32.6 \pm 9.7$ & 0.80 & 0.06 & 0.40 \\
\hline Prepartum & $647 \pm 29$ & $717 \pm 30$ & 0.15 & 0.72 & 0.84 \\
\hline Postpartum & $579 \pm 21$ & $592 \pm 21$ & 0.67 & $<0.01$ & 0.80 \\
\hline ECM $(\mathrm{kg} / \mathrm{d})$ & $40.5 \pm 3.6$ & $37.3 \pm 3.5$ & 0.54 & 0.02 & 0.80 \\
\hline Milk urea $(\mathrm{mmol} / \mathrm{L})$ & $4.9 \pm 0.4$ & $5.0 \pm 0.4$ & 0.87 & 0.69 & 0.97 \\
\hline Milk $\operatorname{SCC}^{3}(\times 1,000$ cells $/ \mathrm{mL})$ & $81 \pm 40$ & $121 \pm 60$ & 0.60 & 0.96 & 0.76 \\
\hline
\end{tabular}

${ }^{1}$ Data are least squares means \pm standard error of the means for the prepartum period (wk -5 to -1 ) and postpartum period (wk 1 to 6 ).

${ }^{2} \mathrm{NE}=$ net energy.

${ }^{3}$ Geometric means and standard error of the means of log-transformed data.

conducted using the SAS 9.1 software package (SAS Institute Inc., Cary, NC).

Analyses of proteome data included a total of 4 iTRAQ data sets from the ProteinPilot output, which were merged into a single file. Accessions with zero sequence coverage (below 95\% confidence) were removed and the protein ratios $\left(\mathrm{H} / \mathrm{L}\right.$ ratios) were $\log _{2}$-transformed before a 1 -sample $t$-test (a paired $t$-test) was performed against a test value of 0 . Accessions with less than 3 replicates $(\mathrm{H} / \mathrm{L}$ ratios) and average fold changes less than or equal to $5 \%$ were removed from the alignment result. The complete alignment result is given in Supplementary Table 1 (available online at http.// www.journalofdairyscience.org/).

Differentially expressed proteins in the liver were correlated with liver TG and plasma variables using the Pearson correlation coefficient. However, because proteome data consisted of protein ratios between cows from the $\mathrm{H}$ and $\mathrm{L}$ groups $(\mathrm{H} / \mathrm{L}$ ratios), liver $\mathrm{TG}$ and plasma data were also converted into $\mathrm{H} / \mathrm{L}$ ratios. The $\mathrm{H} / \mathrm{L}$ ratios for all variables were $\log _{2}$-transformed before the correlation was performed. Liver proteins not correlating with liver TG $(P \geq 0.2)$, and plasma variables not correlating with any liver proteins $(P \geq 0.2)$ were excluded from the output data.

\section{RESULTS}

\section{DM and Energy Intake, BW, and Milk Production}

Table 1 shows DMI, NE intake, and BW in the L and $\mathrm{H}$ groups for the pre- and postpartum periods and ECM, milk urea, and milk SCC in the L and $\mathrm{H}$ groups for the postpartum period. The average daily DMI and
NE intake did not differ between the $\mathrm{L}$ and $\mathrm{H}$ groups prepartum, but tended $(P<0.10)$ to be $21 \%$ lower in the $\mathrm{H}$ group postpartum. Body weight, ECM, milk urea, and milk SCC did not differ between the $\mathrm{L}$ and $\mathrm{H}$ groups postpartum.

\section{Liver and Blood Analyses}

Liver TG, PL, glucose, and glycogen in the $\mathrm{L}$ and $\mathrm{H}$ groups at $-5,1,4$, and 6 wk relative to calving are shown in Figure 1. Liver TG did not differ between the $\mathrm{L}$ and $\mathrm{H}$ groups prepartum, but was 190 and $105 \%$ higher in the $\mathrm{H}$ group at 1 and 4 wk relative to calving, respectively. Liver PL tended $(P<0.10)$ to be $7 \%$ lower in the $\mathrm{H}$ group compared with the $\mathrm{L}$ group during the whole period (sum of wk $-5,1,4$, and 6). Liver glucose level was not different in the $\mathrm{L}$ and $\mathrm{H}$ groups, although liver glucose tended $(P<0.10)$ to be $33 \%$ higher in the $\mathrm{H}$ group compared with the $\mathrm{L}$ group at wk 6 postpartum. Furthermore, liver glucose increased $(P<0.01)$ by $90 \%$ from 1 to $6 \mathrm{wk}$ relative to calving in the $\mathrm{H}$ group. Liver glycogen level did not differ between the $\mathrm{L}$ and $\mathrm{H}$ groups.

Various plasma components in the $\mathrm{L}$ and $\mathrm{H}$ groups are shown for the pre- and postpartum periods in Table 2. None of the plasma components differed between the $\mathrm{L}$ and $\mathrm{H}$ groups prepartum apart from plasma BHBA, which was 17 and $41 \%$ higher in the $\mathrm{H}$ group prepartum $(P<0.05)$ and postpartum $(P<0.01)$, respectively. Postpartum plasma concentrations of NEFA, TBIL, and AST were 43,49 , and $36 \%$ higher $(P<0.05)$ in the $\mathrm{H}$ group compared with the $\mathrm{L}$ group, respectively. Plasma glucose was at the same level in the $\mathrm{L}$ and $\mathrm{H}$ groups, but increased $(P<0.01)$ by $35 \%$ from wk 1 
A

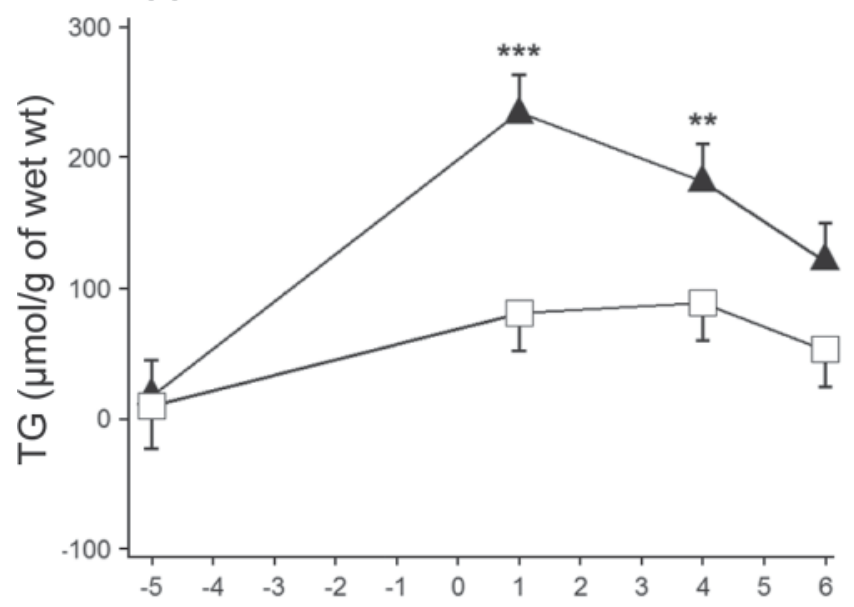

C

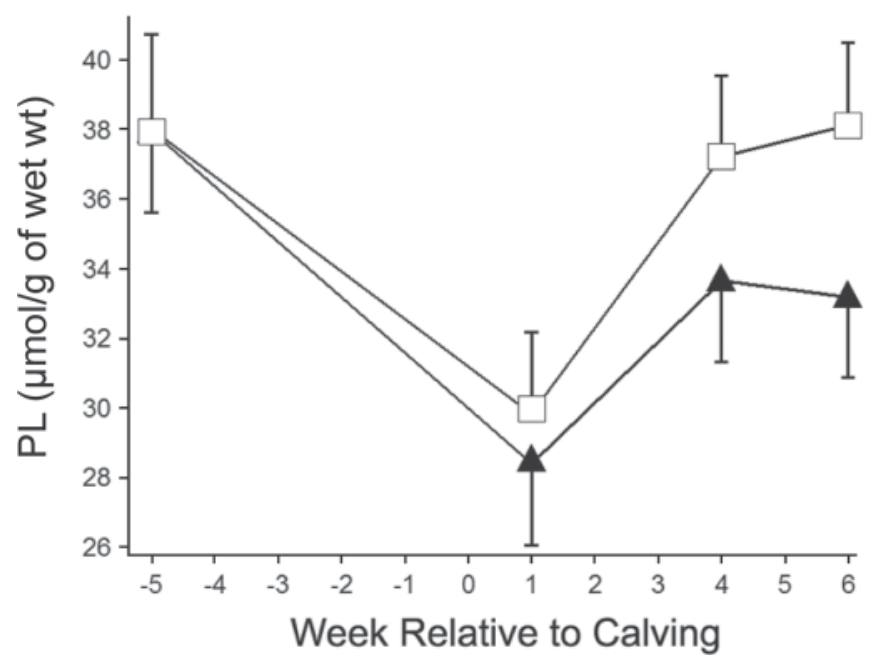

B

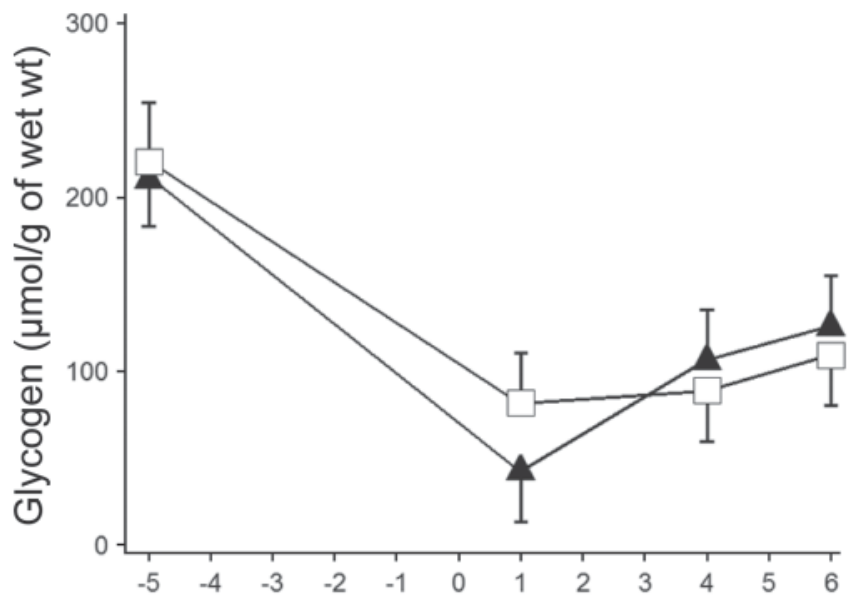

D

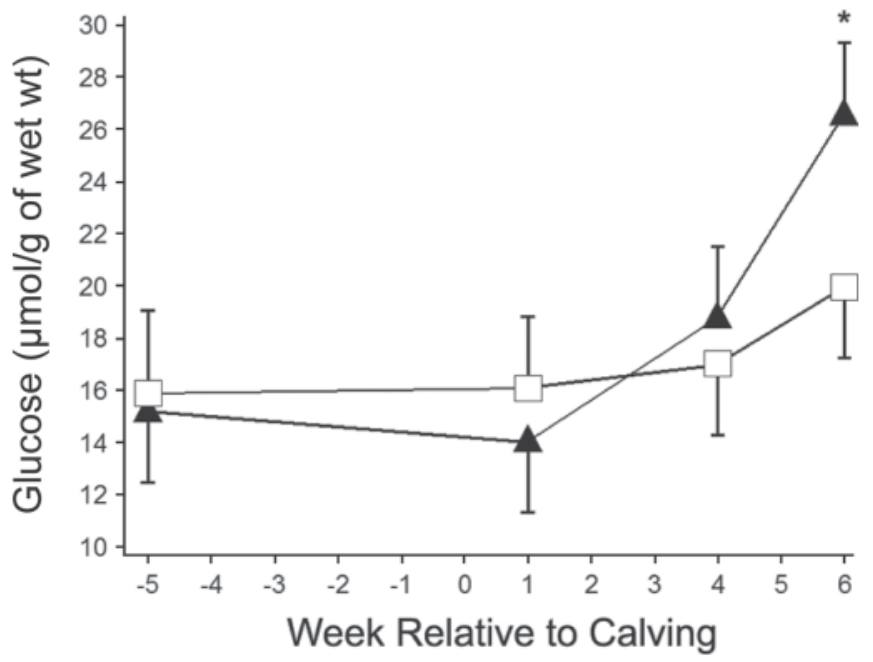

Figure 1. Liver triglycerides (TG; A), glycogen (B), phospholipids (PL; C), and glucose (D) at wk $-5,1,4$, and 6 in cows selected for low $(\square)$ or high $(\mathbf{\Lambda})$ liver triglycerides at wk 1 postpartum $\left({ }^{*} P \leq 0.10 ;{ }^{* *} P<0.05 ;{ }^{* * *} P<0.01\right)$. Data are least squares means \pm standard errors.

to 6 postpartum in both groups (not shown in Table 2). Plasma total cholesterol, glutamate dehydrogenase and GGT were identical in the $\mathrm{L}$ and $\mathrm{H}$ groups both pre- and postpartum. Furthermore, the levels of plasma calcium, protein, urea, AP, TG, PL, and TBA were the same in the $\mathrm{L}$ and $\mathrm{H}$ groups (data not shown).

\section{Differential Protein Expression}

The result of the global proteome analysis is shown in Table 3. We detected 29 differentially $(P \leq 0.05)$ expressed proteins between the $\mathrm{L}$ and $\mathrm{H}$ groups, and 17 proteins that tended $(P \leq 0.10)$ toward a differential expression. In total, 46 proteins were grouped according to functional ontology to enable a biological and molecular interpretation of the relative difference in protein abundance. The 46 proteins were involved in AA metabolism (3), bilirubin metabolism (2), carbohydrate metabolism (12), cell redox homeostasis (5), lipid metabolism (6), other metabolic processes (9), protein folding and turnover (3), and other functions (6). The proteins involved in AA metabolism, carbohydrate metabolism, cell redox homeostasis, lipid metabolism, and other metabolic processes are shown in Figure 2.

The proteins affected in the AA metabolism were involved in degradation. Arginase and AST were more abundant $(P \leq 0.05)$ in the $\mathrm{H}$ group compared with the L group, whereas 3 -hydroxyisobutyrate dehydrogenase $(P<0.01)$ involved in valine, leucine, and isoleucine degradation was relatively less abundant in the $\mathrm{H}$ group. 
Table 2. Various plasma components in cows selected for low (L) or high (H) liver triglycerides (TG) at wk 1 postpartum

\begin{tabular}{|c|c|c|c|c|c|}
\hline Variable $^{1}$ & \multicolumn{2}{|c|}{ Liver TG $(\mathrm{l}-\mathrm{TG})^{2}$} & \multicolumn{3}{|c|}{$P$-value } \\
\hline \multicolumn{6}{|c|}{$\overline{\mathrm{NEFA}^{3}(\mathrm{mEq} / \mathrm{L})}$} \\
\hline Postpartum & $0.46 \pm 0.06$ & $0.80 \pm 0.10$ & 0.02 & 0.36 & 0.28 \\
\hline \multicolumn{6}{|l|}{$\mathrm{TC}(\mathrm{mmol} / \mathrm{L})$} \\
\hline Prepartum & $2.3 \pm 0.2$ & $2.1 \pm 0.2$ & 0.57 & $<0.01$ & 0.46 \\
\hline Prepartum & $2.5 \pm 0.3$ & $2.6 \pm 0.3$ & 0.85 & 0.88 & 0.63 \\
\hline Postpartum & $2.5 \pm 0.3$ & $2.6 \pm 0.3$ & 0.84 & $<0.01$ & 0.47 \\
\hline \multicolumn{6}{|c|}{$\mathrm{BHBA}^{3}(\mathrm{mmol} / \mathrm{L})$} \\
\hline Prepartum & $0.54 \pm 0.03$ & $0.65 \pm 0.03$ & 0.04 & 0.08 & 0.11 \\
\hline Postpartum & $0.84 \pm 0.04$ & $1.42 \pm 0.07$ & $<0.01$ & 0.01 & 0.03 \\
\hline \multicolumn{6}{|c|}{ Total bilirubin $(\mu \mathrm{mol} / \mathrm{L})$} \\
\hline Prepartum & $2.9 \pm 0.5$ & $3.0 \pm 0.5$ & 0.88 & 0.78 & 0.72 \\
\hline Prepartum & $50.4 \pm 6.3$ & $48.4 \pm 6.3$ & 0.83 & 0.57 & 0.83 \\
\hline Postpartum & $62.3 \pm 8.0$ & $97.0 \pm 8.0$ & 0.01 & $<0.01$ & 0.02 \\
\hline \multicolumn{6}{|l|}{$\operatorname{GGT}(\mathrm{U} / \mathrm{L})$} \\
\hline Prepartum & $25.1 \pm 3.4$ & $26.6 \pm 3.4$ & 0.76 & 0.63 & 0.17 \\
\hline Postpartum & $24.6 \pm 7.8$ & $40.8 \pm 7.8$ & 0.18 & 0.52 & 0.22 \\
\hline
\end{tabular}

${ }^{1} \mathrm{TC}=$ total cholesterol; GDH $=$ glutamate dehydrogenase; AST $=$ aspartate aminotransferase; GGT $=\gamma$-glutamyltransferase.

${ }^{2}$ Data are least squares means \pm standard error of the means for the prepartum period (wk -5 to -1 ) and postpartum period (wk 1 to 6 ).

${ }^{3}$ Geometric means and standard error of the means of log-transformed data.

The proteins affected in the carbohydrate metabolism were primarily involved in gluconeogenesis. Propionyl-CoA carboxylase, lactate dehydrogenase, and pyruvate carboxylase were more abundant $(P \leq 0.05)$ in the $\mathrm{H}$ group compared with the $\mathrm{L}$ group, whereas the amount of fructose-1,6-bisphosphatase 1 was lower in the $\mathrm{H}$ group $(P \leq 0.05)$. Alcohol dehydrogenase $(P$ $\leq 0.05)$ and glycerol-3-phosphate dehydrogenase $(P<$ $0.10)$, involved in glycerol metabolism, were relatively less abundant in the $\mathrm{H}$ group compared with the $\mathrm{L}$ group. For proteins involved in glycogenesis, uridine-5'triphosphate (UTP)-glucose-1-phosphate uridylyltransferase $(P<0.10)$ was more abundant in the $\mathrm{H}$ group compared with the L group, whereas phosphoglucomutase-2 $(\mathrm{PGM} 2)$ protein $(P<0.01)$ was observed in lower amounts in the $\mathrm{H}$ group.

The proteins affected in the cell redox homeostasis were involved in protection against oxidative stress. Peroxiredoxin-2, protein disulfide isomerase, and thioredoxin were more abundant $(P \leq 0.05)$ in the $\mathrm{H}$ group compared with the L group. In addition, cytochrome P450 2E1 $(P \leq 0.05)$ and GTP:AMP phosphotransferase $(P<0.10)$, which are involved in metabolic processes associated with oxidative metabolism, were also more abundant in the $\mathrm{H}$ group compared with the L group.
The proteins affected in the lipid metabolism were involved in FA oxidation. Acyl-CoA synthetase longchain family member 1 (ACSL1) and very long-chain specific acyl-CoA dehydrogenase (VLCAD) were more abundant $(P \leq 0.05)$ in the $\mathrm{H}$ compared with the $\mathrm{L}$ group, whereas hydroxyacyl-CoA dehydrogenase was relatively less abundant $(P \leq 0.05)$ in the $\mathrm{H}$ group. In addition, 2,4-dienoyl CoA reductase 1 and dodecenoylCoA delta isomerase involved in the oxidation of unsaturated FA were relatively less abundant $(P \leq 0.05)$ in the $\mathrm{H}$ group compared with the $\mathrm{L}$ group. Furthermore, 4-trimethylaminobutyraldehyde dehydrogenase involved in carnitine biosynthesis was relatively less abundant $(P<0.01)$ in the $\mathrm{H}$ group compared with the $\mathrm{L}$ group.

Four proteins involved in other metabolic processes (i.e., oxidative liver metabolism) were less abundant in the $\mathrm{H}$ group compared with the $\mathrm{L}$ group. These proteins were alcohol dehydrogenase 6 (class $\mathrm{V} ; P<0.01$ ); alcohol dehydrogenase 4 (ADH4) protein $(P \leq 0.05)$; amine oxidase (flavin-containing) $\mathrm{B}(P<0.10)$; and aldo-keto reductase family 1 , member $\mathrm{C}(P \leq 0.05)$. Three proteins with other functions (i.e., cytoskeleton organization) were also less abundant in the $\mathrm{H}$ group compared with the L group. These proteins were adenylyl cyclase-associated protein $1(P \leq 0.05)$, annexin 
A2 $(P<0.01)$, and non-muscle myosin heavy chain $(P$ $<0.01)$. For proteins involved in bilirubin metabolism, flavin reductase $(P<0.10)$ was relatively more abundant, whereas uridine diphosphate (UDP)-glucuronosyltransferase 1A1 (UGT1A1) protein $(P<0.10)$ was relatively less abundant in the $\mathrm{H}$ group compared with the L group.

\section{Liver Protein Correlations with Liver Triglycerides and Plasma Variables}

The Pearson correlations between liver proteins and liver TG, and liver proteins and plasma variables are presented in Table 4. Plasma glucose did not correlate with any liver proteins $(P \leq 0.2)$, but was included due to the biological relevance.

\section{- Amino Acid Metabolism $\square$ Carbohydrate Metabolism $\square$ Cell Redox Homeostasis $\square$ Lipid Metabolism Other Metabolic Processes}

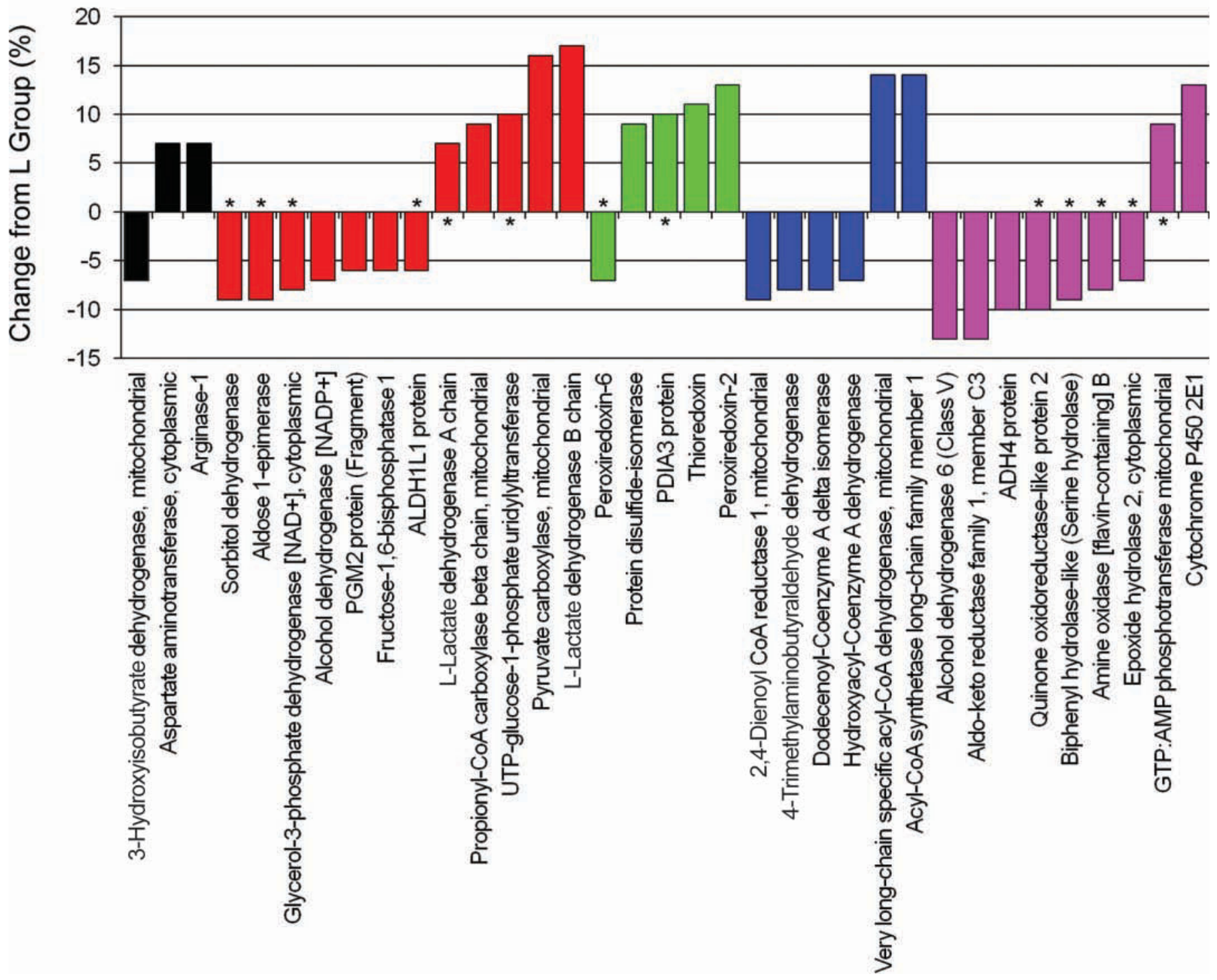

Figure 2. An overview of differentially expressed $(P \leq 0.05)$ proteins between cows selected for low $(\mathrm{L})$ or high $(\mathrm{H})$ liver triglycerides at wk 1 postpartum. Proteins that tended $(P \leq 0.10)$ toward a differential expression are marked with an asterisk $(*)$. PGM2 $=$ phosphoglucomutase-2; ALDH1L1 = aldehyde dehydrogenase 1 family, member L1; UTP = uridine-5'-triphosphate; PDIA3 = protein disulfide isomerase family A, member 3; ADH4 = alcohol dehydrogenase 4; GTP = guanosine-5'-triphosphate. Color version available in the online PDF. 


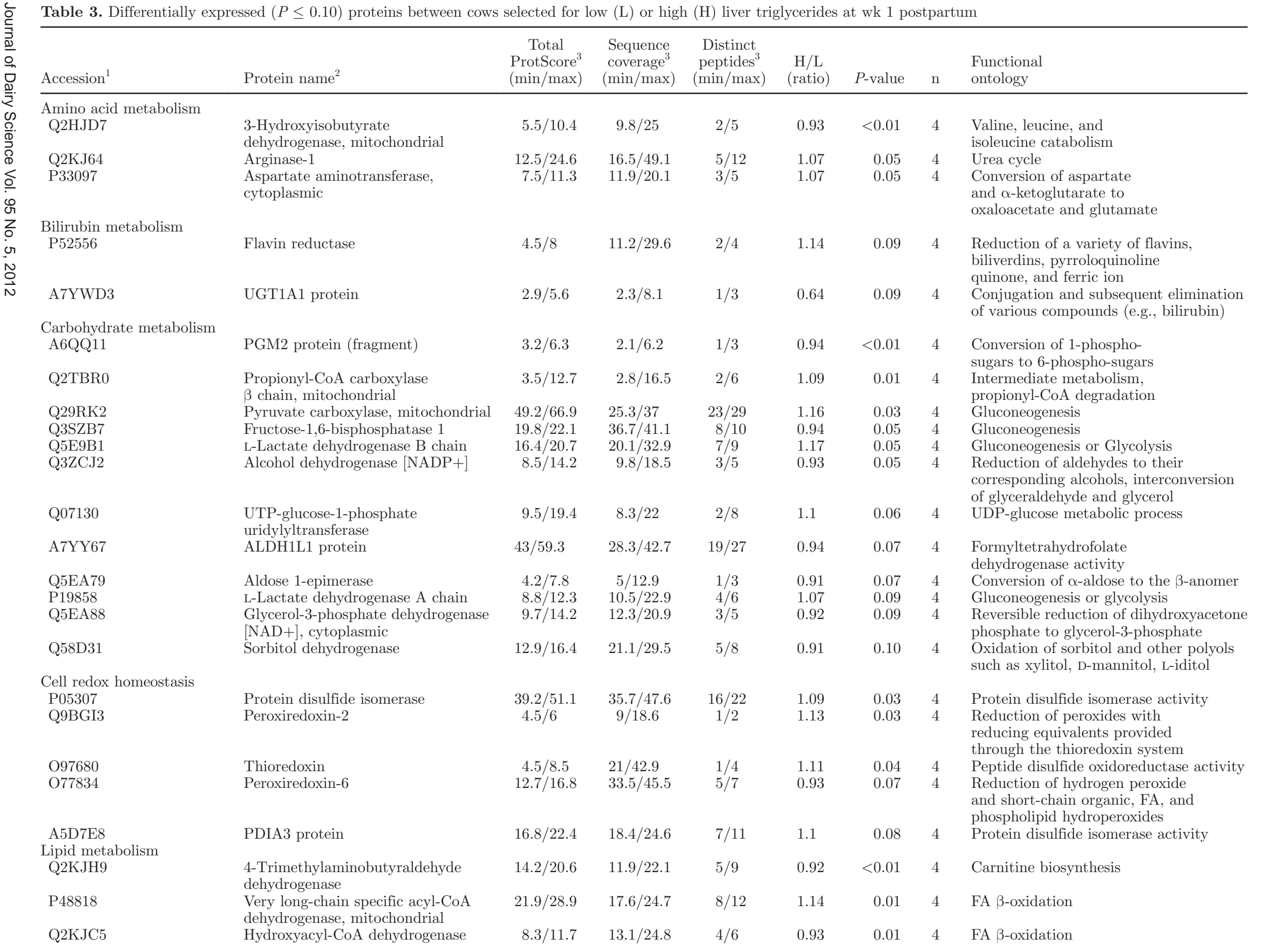


Table 3 (Continued). Differentially expressed $(P \leq 0.10)$ proteins between cows selected for low $(\mathrm{L})$ or high $(\mathrm{H})$ liver triglycerides at wk 1 postpartum

\begin{tabular}{|c|c|c|c|c|c|c|c|c|}
\hline Accession $^{1}$ & Protein name ${ }^{2}$ & $\begin{array}{c}\text { Total } \\
\text { ProtScore } \\
(\min / \max )\end{array}$ & $\begin{array}{l}\text { Sequence } \\
\text { coverage }^{3} \\
(\min / \max )\end{array}$ & $\begin{array}{l}\text { Distinct } \\
\text { peptides } \\
(\min / \max )\end{array}$ & $\begin{array}{l}\mathrm{H} / \mathrm{L} \\
\text { (ratio) }\end{array}$ & $P$-value & $\mathrm{n}$ & $\begin{array}{l}\text { Functional } \\
\text { ontology }\end{array}$ \\
\hline Q2NL38 & $\begin{array}{l}\text { Dodecenoyl-CoA delta isomerase } \\
\text { (3,2-trans-enoyl-CoA isomerase) }\end{array}$ & $2.8 / 5.2$ & $3.3 / 11.6$ & $1 / 3$ & 0.92 & 0.02 & 4 & FA $\beta$-oxidation of unsaturated FA \\
\hline Q0VCZ8 & $\begin{array}{l}\text { Acyl-CoA synthetase long-chain } \\
\text { family member } 1\end{array}$ & $2.3 / 6.9$ & $2.6 / 6.4$ & $1 / 3$ & 1.14 & 0.03 & 4 & $\begin{array}{l}\text { Activation of long-chain FA for } \\
\text { both synthesis of cellular lipids, } \\
\text { and degradation via } \beta \text {-oxidation }\end{array}$ \\
\hline Q0IIJ8 & $\begin{array}{l}2,4 \text {-Dienoyl CoA reductase } \\
1, \text { mitochondrial }\end{array}$ & $3.5 / 5.1$ & $6.7 / 9.1$ & $1 / 2$ & 0.91 & 0.03 & 4 & FA $\beta$-oxidation of unsaturated FA \\
\hline \multicolumn{9}{|c|}{ Other metabolic processes } \\
\hline Q2KII0 & Alcohol dehydrogenase 6 (Class V) & $16.3 / 19.7$ & $24.8 / 28$ & $7 / 9$ & 0.87 & $<0.01$ & 4 & Alcohol dehydrogenase (NAD) activity \\
\hline A6QPF3 & ADH4 protein & $4.2 / 10$ & $2.9 / 18.2$ & $1 / 5$ & 0.9 & 0.02 & 4 & Alcohol dehydrogenase (NAD) activity \\
\hline Q2TBN0 & $\begin{array}{l}\text { Aldo-keto reductase family } 1, \\
\text { member C3 ( } 3 \text { - } \alpha \text { hydroxysteroid } \\
\text { dehydrogenase, type II) }\end{array}$ & $22 / 31.4$ & $24.8 / 44.3$ & $9 / 13$ & 0.87 & 0.03 & 4 & $\begin{array}{l}\text { Multifunctional enzyme involved } \\
\text { in androgen, estrogen, and } \\
\text { progesterone metabolism }\end{array}$ \\
\hline O18963 & Cytochrome P450 2E1 & $6.4 / 10.7$ & $4.8 / 11.9$ & $2 / 4$ & 1.13 & 0.04 & 4 & Oxidoreductase activity \\
\hline P08760 & $\begin{array}{l}\text { GTP:AMP phosphotransferase } \\
\text { mitochondrial }\end{array}$ & $2.1 / 6.2$ & $4.8 / 17.2$ & $1 / 3$ & 1.09 & 0.06 & 4 & AMP phosphorylation \\
\hline Q17QK4 & Epoxide hydrolase 2, cytoplasmic & $7.8 / 15.2$ & $4.7 / 16.9$ & $2 / 7$ & 0.93 & 0.07 & 4 & Hydrolase activity \\
\hline P56560 & Amine oxidase [flavin-containing] B & $3.5 / 8.9$ & $4.8 / 13.7$ & $2 / 4$ & 0.92 & 0.07 & 4 & $\begin{array}{l}\text { Oxidative deamination of biogenic } \\
\text { and xenobiotic amines }\end{array}$ \\
\hline A6QQF5 & Quinone oxidoreductase-like protein 2 & $4.6 / 6.5$ & $8.3 / 13.8$ & $2 / 3$ & 0.9 & 0.07 & 4 & Oxidoreductase activity \\
\hline Q2KIX6 & $\begin{array}{l}\text { Biphenyl hydrolase-like } \\
\text { (serine hydrolase) }\end{array}$ & $2.5 / 5.5$ & $11 / 18.9$ & $1 / 2$ & 0.91 & 0.07 & 3 & Hydrolase activity \\
\hline \multicolumn{9}{|c|}{$\begin{array}{l}\text { Protein folding } \\
\text { and turnover }\end{array}$} \\
\hline Q58DT1 & $60 \mathrm{~S}$ ribosomal protein $\mathrm{L} 7$ & $2.2 / 4$ & $7.7 / 8.1$ & $1 / 2$ & 1.2 & $<0.01$ & 4 & Translation \\
\hline Q9XSI3 & 60S ribosomal protein L10 & $1.7 / 2$ & $5.6 / 5.6$ & $1 / 1$ & 1.3 & $<0.01$ & 3 & Translation \\
\hline P02510 & Alpha-crystallin B chain & $1.5 / 2$ & $6.3 / 6.3$ & $1 / 1$ & 1.47 & 0.07 & 4 & Protein homodimerization activity \\
\hline \multicolumn{9}{|c|}{ Other functions } \\
\hline O02717 & $\begin{array}{l}\text { Non-muscle myosin heavy } \\
\text { chain (fragment) }\end{array}$ & $2.4 / 5.7$ & $1.8 / 3.4$ & $1 / 2$ & 0.88 & $<0.01$ & 4 & Cytoskeletal stress fiber \\
\hline P04272 & Annexin A2 & $3.3 / 8.7$ & $5.3 / 14.7$ & $1 / 3$ & 0.91 & $<0.01$ & 3 & Phospholipase inhibitor activity \\
\hline Q3SYV4 & Adenylyl cyclase-associated protein 1 & $3.1 / 6.8$ & $1.7 / 10.4$ & $1 / 2$ & 0.93 & 0.03 & 4 & Direct regulation of filament dynamics \\
\hline Q3SZK8 & $\begin{array}{l}\text { Ezrin-radixin-moesin-binding } \\
\text { phosphoprotein } 50\end{array}$ & $3.4 / 4.4$ & $4.9 / 10.3$ & $1 / 2$ & 1.14 & 0.04 & 3 & Cellular phosphate ion homeostasis \\
\hline A7MBF1 & AGXT protein & $2 / 4.1$ & $3.1 / 7$ & $1 / 2$ & 1.17 & 0.05 & 3 & \multirow{2}{*}{$\begin{array}{l}\text { Class-V pyridoxal phosphate- } \\
\text { dependent aminotransferase family } \\
\text { May be involved in cell cycle regulation }\end{array}$} \\
\hline Q32PF3 & $\begin{array}{l}\text { PEST proteolytic signal-containing } \\
\text { nuclear protein }\end{array}$ & $2 / 2$ & $9 / 9$ & $1 / 1$ & 1.26 & 0.09 & 3 & \\
\hline
\end{tabular}

${ }^{1}$ Accessions with at least 3 replicates (H/L ratios) are shown and sorted by ascending $P$-values within functional ontology.

₹. $\quad{ }^{2}$ UGT1A1 = uridine diphosphate (UDP)-glucuronosyltransferase 1A1; PGM2 = phosphoglucomutase-2; UTP = uridine-5'-triphosphate; ALDH1L1 = aldehyde dehydrogenase 1 ก. family, member L1; PDIA3 = protein disulfide isomerase family A, member 3; ADH4 = alcohol dehydrogenase 4; GTP = guanosine-5'-triphosphate; AGXT = alanine-glyoxylate aminotransferase; PEST = proline, glutamate, serine, and threonine sequence.

${ }^{3}$ The minimum (min) and maximum (max; within replicates) total ProtScore (from ProteinPilot 1.0 software; Applied Biosystems Inc., Foster City, CA), sequence coverage, and $\delta$ number of distinct peptides ( $\geq 95 \%$ confidence). 


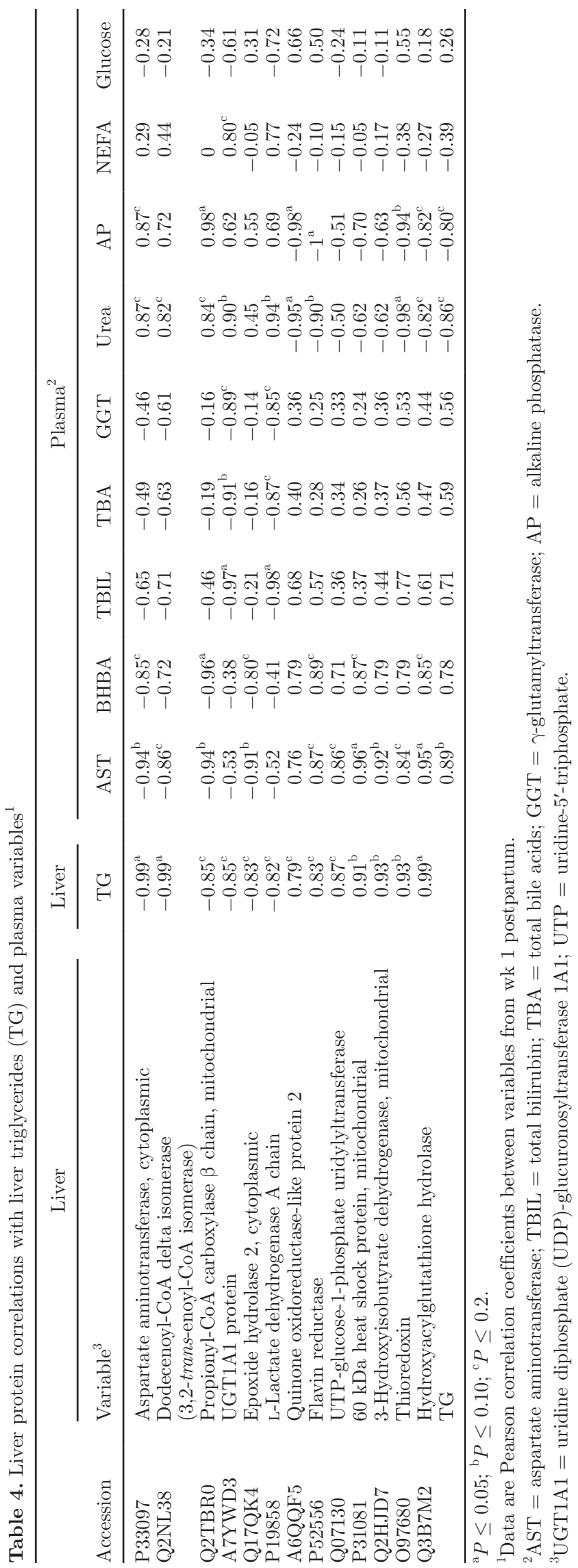

Thirteen liver proteins from the proteome analysis were found to correlate either negatively (6) or positively (7) with liver TG $(P \leq 0.2)$. Plasma variables that correlated $(P \leq 0.2)$ with liver proteins were ordered according to the number of correlations between the plasma variable and liver proteins (count $\geq 2$ ). For the group of liver proteins that correlated negatively with liver TG, a numerically negative correlation existed with plasma AST (4), BHBA (3), TBIL (2), TBA (2), and GGT (2), and a numerically positive correlation with plasma urea (5) and AP (2). In contrast, a numerically positive correlation existed with plasma AST (6) and BHBA (3), and a numerically negative correlation with plasma urea (4) and AP (4) for the group of liver proteins that correlated positively with liver TG. Three of the plasma variables correlated with liver TG [i.e., AP and urea were negatively correlated $(P \leq 0.2)$ and AST was positively correlated $(P \leq 0.10)]$.

\section{DISCUSSION}

The cows with a high liver TG content in early lactation mobilized more body tissue as indicated by higher plasma NEFA concentrations postpartum and a tendency toward a lower feed intake. These results are consistent with previous studies as reviewed by Ingvartsen and Andersen (2000). Over-conditioned cows experience a more severe decrease in prepartum feed intake and a more severe negative energy balance with a concurrent increase in the incidence of fatty liver (Rukkwamsuk et al., 1998; Ingvartsen, 2006).

Liver glucose increased from wk 1 to 6 postpartum in the cows with a high liver TG content, whereas plasma glucose increased from wk 1 to 6 postpartum in all cows. Surprisingly, postpartum plasma glucose did not decrease in the present study, contrary to former studies showing a postpartum decrease in plasma glucose, reflecting a greater glucose demand with the onset of lactation (Ingvartsen, 2006; Hammon et al., 2009). However, as the plasma glucose concentration of all cows did not differ postpartum, no association appears to exist between plasma glucose concentration and liver TG content. Liver PL tended to be lower in the cows with a high liver TG content in early lactation, indicating a reduced PL synthesis, which may inhibit the secretion of VLDL from the liver (Van den Top et al., 1996; Bobe et al., 2004).

The cows with a high liver TG content in early lactation had higher postpartum plasma concentrations of NEFA, BHBA, TBIL, and AST. These plasma components are associated with the development of fatty liver, and our results are consistent with previous findings in the literature (Van den Top et al., 1996; Bobe et al., 2004; Kalaitzakis et al., 2006; Hammon et 
al., 2009). We found no effects of liver TG content in early lactation on plasma protein, urea, AP, and TBA, although these plasma components have been associated with fatty liver (Bobe et al., 2004). However, these associations are generally weak and may require larger samples to detect.

The proteome analysis in the present study indicated an increased FA oxidation in the cows with a high liver TG content in early lactation. The amounts of acyl-CoA synthetase long-chain family member 1 and very longchain specific acyl-CoA dehydrogenase were increased in the cows with a high liver TG content. Acyl-CoA synthetase long-chain family member 1 activates FA primarily for FA oxidation and TG incorporation because FA synthesis is negligible in the cow liver (Emery, 1979). Very long-chain specific acyl-CoA dehydrogenase catalyzes the initial, rate-limiting step of FA oxidation (i.e., oxidation of palmitoyl-CoA, myristoyl-CoA, and stearoyl-CoA; McAndrew et al., 2008). Our data do not support previous results in early lactation dairy cows that have shown a negative correlation between $\beta$-oxidation of palmitate and liver TG content (Grum et al., 2002). However, the degree of liver TG accumulation was much lower in the previous study compared with the present study (6 versus $21 \%$ TG, on average). Thus, the 2 studies may represent the mild and a more severe state of TG accumulation, respectively.

The expression of auxiliary proteins involved in the oxidation of unsaturated FA was lower in the cows with a high liver TG content in early lactation. It is likely that the cows with a high liver TG content had an increased influx of SFA into the liver due to the relatively high proportion of SFA in adipose tissue (Rukkwamsuk et al., 1999a; French et al., 2000). Consequently, cows with an increased liver TG content may have relatively lower amounts of unsaturated FA in the liver.

The observed regulation of antioxidant proteins indicated ongoing oxidative stress in the cows with a high liver TG content in early lactation mainly through the increased cytochrome P450 2E1 in the liver, which is a major player in oxidative metabolism (Koop, 1992). In agreement with previous results, our data indicate that increased levels of intracellular FA and production of toxic products of lipid peroxidation and glucose autoxidation lead to oxidative stress in cows with a high liver TG content (Mudron̆ et al., 1999; Abd Ellah et al., 2004; Sejersen and Rattan, 2009).

The proteome analysis revealed that arginase and AST were relatively high in the cows with a high liver TG content in early lactation, indicating an increased urea synthesis and AA degradation. It is likely that the levels of AA degradation and urea synthesis are increased because arginase catalyzes the final step in urea synthesis (Watford, 2003). Nonetheless, blood urea was the same among the cows with a low or high liver TG content in early lactation, whereas liver TG content was negatively correlated with plasma urea concentrations. The abundances of these enzymes may, therefore, not correlate with their enzymatic activities.

The proteome results indicated that gluconeogenesis was not impaired in the cows with a high liver TG content in early lactation, which is in agreement with previous findings (Hammon et al., 2009). However, other studies have shown that gluconeogenesis is reduced by lipid infiltration (Cadórniga-Valiño et al., 1997; Rukkwamsuk et al., 1999b). Our findings support the existing knowledge that lactate and propionate are used for gluconeogenesis in cows with a high liver TG content in early lactation due to increased amounts of lactate dehydrogenase and propionyl-CoA carboxylase (Danfaer et al., 1995; Aschenbach et al., 2010). Nevertheless, glucose and glycerol interconversion may be decreased in cows with a high liver TG content in early lactation due to decreased amounts of alcohol dehydrogenase and glycerol-3-phosphate dehydrogenase (Hagopian et al., 2008).

In the present study, the differentially expressed proteins were correlated with liver TG content and plasma variables. However, the correlations should be considered with caution due to the small sample size. Nevertheless, the proteins that correlated negatively or positively with liver TG content also correlated negatively or positively with plasma AST, BHBA, TBIL, TBA, and GGT, respectively. Although most of these plasma variables were uncorrelated with liver TG content, this consistent pattern indicates that plasma AST, BHBA, TBIL, TBA, and GGT increase when liver TG content increases. Previous results have shown that these plasma components are correlated with liver TG content in dairy cows (Bobe et al., 2004; Kalaitzakis et al., 2006).

The amounts of liver propionyl-CoA carboxylase and lactate dehydrogenase were negatively correlated with liver TG content. These proteins may leak into the bloodstream when liver TG content increases, but remain relatively more abundant in the liver of cows with a high liver TG content in early lactation. The amounts of thioredoxin and hydroxyacylglutathione hydrolase were positively correlated with liver TG content, which may reflect the need for their well-known functions in controlling oxidative stress. Uridine diphosphate glucuronosyltransferase $1 \mathrm{~A} 1$ protein and flavin reductase were either negatively or positively correlated with liver TG content, respectively. These findings indicate that bilirubin is retained in the liver to protect against oxidative stress (Ritter et al., 1992; Sedlak and Snyder, 2004). In addition, the amount of dodecenoyl-CoA delta isomerase was negatively correlated with liver TG 
content, also indicating that oxidation of unsaturated FA in the liver is relatively decreased in cows with a high liver TG content in early lactation.

\section{CONCLUSIONS}

Our study is the first to investigate the proteome of dairy cows with naturally occurring fatty liver in early lactation. Our liver proteome analysis indicated that a high liver TG content in early lactation dairy cows is associated with increased oxidation of SFA, oxidative stress, and urea synthesis and decreased oxidation of unsaturated FA, whereas liver gluconeogenesis is apparently not impaired by an increased liver TG content. We suggest that future studies investigate the sensitivity and specificity of plasma AST, BHBA, TBIL, TBA, and GGT for potential use as blood-based biomarkers for fatty liver. In addition, we speculate that some of the liver proteins that correlated with liver TG may leak into the bloodstream (e.g., propionyl-CoA carboxylase and lactate dehydrogenase). However, this requires further investigation of blood samples.

\section{ACKNOWLEDGMENTS}

The authors thank B. M. Damgaard (Department of Animal Science, Aarhus University, AU Foulum, Tjele, Denmark) for taking tissue and blood samples, K. Kristensen (Department of Agroecology, Aarhus University) for helping with statistical analyses, M. Bjerring (Department of Animal Science, Aarhus University) for helping with SAS programming, and D. Thomassen, L. Jeppesen, C. Berthelsen, and S. H. Smed (all of (Department of Animal Science, Aarhus University) for their technical assistance. The project was supported by research grants from the Danish Council for Independent Research, Technology and Production Sciences (Copenhagen, Denmark).

\section{REFERENCES}

Abd Ellah, M. R., K. Niishimori, M. Goryo, K. Okada, and J. Yasuda. 2004. Glutathion peroxidase and glucose-6-phosphate dehydrogenase activities in bovine blood and liver. J. Vet. Med. Sci. 66:1219-1221.

Aebersold, R., and M. Mann. 2003. Mass spectrometry-based proteomics. Nature 422:198-207.

Andersen, J. B., D. G. Mashek, T. Larsen, M. O. Nielsen, and K. L. Ingvartsen. 2002. Effects of hyperinsulinaemia under euglycaemic condition on liver fat metabolism in dairy cows in early and midlactation. J. Vet. Med. A Physiol. Pathol. Clin. Med. 49:65-71.

Aschenbach, J. R., N. B. Kristensen, S. S. Donkin, H. M. Hammon, and G. B. Penner. 2010. Gluconeogenesis in dairy cows: The secret of making sweet milk from sour dough. IUBMB Life 62:869-877.

Bergman, E. N. 1971. Hyperketonemia-ketogenesis and ketone body metabolism. J. Dairy Sci. 54:936-948.
Bobe, G., J. W. Young, and D. C. Beitz. 2004. Invited review: Pathology, etiology, prevention, and treatment of fatty liver in dairy cows. J. Dairy Sci. 87:3105-3124.

Boden, G. 1998. Free fatty acids (FFA), a link between obesity and insulin resistance. Front. Biosci. 3:d169-d175.

Cadórniga-Valiño, C., R. R. Grummer, L. E. Armentano, S. S. Donkin, and S. J. Bertics. 1997. Effects of fatty acids and hormones on fatty acid metabolism and gluconeogenesis in bovine hepatocytes. J. Dairy Sci. 80:646-656.

Danfaer, A., V. Tetens, and N. Agergaard. 1995. Review and an experimental study on the physiological and quantitative aspects of gluconeogenesis in lactating ruminants. Comp. Biochem. Physiol. B Biochem. Mol. Biol. 111:201-210.

Drackley, J. K. 1999. ADSA Foundation Scholar Award. Biology of dairy cows during the transition period: The final frontier? J. Dairy Sci. 82:2259-2273.

Emery, R. S. 1979. Deposition, secretion, transport and oxidation of fat in ruminants. J. Anim. Sci. 48:1530-1537.

Emery, R. S., J. S. Liesman, and T. H. Herdt. 1992. Metabolism of long chain fatty acids by ruminant liver. J. Nutr. 122:832-837.

French, P., C. Stanton, F. Lawless, E. G. O'Riordan, F. J. Monahan, P. J. Caffrey, and A. P. Moloney. 2000. Fatty acid composition, including conjugated linoleic acid, of intramuscular fat from steers offered grazed grass, grass silage, or concentrate-based diets. J. Anim. Sci. 78:2849-2855.

Grum, D. E., J. K. Drackley, and J. H. Clark. 2002. Fatty acid metabolism in liver of dairy cows fed supplemental fat and nicotinic acid during an entire lactation. J. Dairy Sci. 85:3026-3034.

Hagopian, K., J. J. Ramsey, and R. Weindruch. 2008. Enzymes of glycerol and glyceraldehyde metabolism in mouse liver: Effects of caloric restriction and age on activities. Biosci. Rep. 28:107-115.

Hammon, H. M., G. Stürmer, F. Schneider, A. Tuchscherer, H. Blum, T. Engelhard, A. Genzel, R. Staufenbiel, and W. Kanitz. 2009. Performance and metabolic and endocrine changes with emphasis on glucose metabolism in high-yielding dairy cows with high and low fat content in liver after calving. J. Dairy Sci. 92:1554-1566.

Harano, Y., M. Ohtsuki, M. Ida, H. Kojima, M. Harada, T. Okanishi, A. Kashiwagi, Y. Ochi, S. Uno, and Y. Shigeta. 1985. Direct automated assay method for serum or urine levels of ketone bodies. Clin. Chim. Acta 151:177-183.

Ingvartsen, K. L. 2006. Feeding- and management-related diseases in the transition cow-Physiological adaptations around calving and strategies to reduce feeding-related diseases. Anim. Feed Sci. Technol. 126:175-213.

Ingvartsen, K. L., and J. B. Andersen. 2000. Integration of metabolism and intake regulation: A review focusing on periparturient animals. J. Dairy Sci. 83:1573-1597.

Kalaitzakis, E., N. Roubies, N. Panousis, K. Pourliotis, E. Kaldrymidou, and H. Karatzias. 2006. Evaluation of ornithine carbamoyl transferase and other serum and liver-derived analytes in diagnosis of fatty liver and postsurgical outcome of left-displaced abomasum in dairy cows. J. Am. Vet. Med. Assoc. 229:1463-1471.

Katoh, N. 2002. Relevance of apolipoproteins in the development of fatty liver and fatty liver-related peripartum diseases in dairy cows. J. Vet. Med. Sci. 64:293-307.

Koop, D. R. 1992. Oxidative and reductive metabolism by cytochrome P450 2E1. FASEB J. 6:724-730.

Kuhla, B., D. Albrecht, S. Kuhla, and C. C. Metges. 2009. Proteome analysis of fatty liver in feed-deprived dairy cows reveals interaction of fuel sensing, calcium, fatty acid, and glycogen metabolism. Physiol. Genomics 37:88-98.

Mashek, D. G., K. L. Ingvartsen, J. B. Andersen, M. Vestergaard, and T. Larsen. 2001. Effects of a four-day hyperinsulinemic-euglycemic clamp in early and mid-lactation dairy cows on plasma concentrations of metabolites, hormones, and binding proteins. Domest. Anim. Endocrinol. 21:169-185.

McAndrew, R. P., Y. Wang, A.-W. Mohsen, M. He, J. Vockley, and J. J. Kim. 2008. Structural basis for substrate fatty acyl chain specificity: Crystal structure of human very-long-chain acyl-CoA dehydrogenase. J. Biol. Chem. 283:9435-9443. 
Mudroň, P., J. Rehage, K. Qualmann, H.-P. Sallmann, and H. Scholz. 1999. A study of lipid peroxidation and vitamin $\mathrm{E}$ in dairy cows with hepatic insufficiency. Zentralbl. Veterinarmed. A 46:219224.

Reid, I. M. 1980. Incidence and severity of fatty liver in dairy cows. Vet. Rec. 107:281-284.

Reid, I. M., C. J. Roberts, R. A. Collins, and S. M. Dew. 1979. Fatty liver and infertility in dairy cows in early lactation. Proc. Nutr. Soc. 38:67A.

Ritter, J. K., F. Chen, Y. Y. Sheen, H. M. Tran, S. Kimura, M. T. Yeatman, and I. S. Owens. 1992. A novel complex locus UGT1 encodes human bilirubin, phenol, and other UDP-glucuronosyltransferase isozymes with identical carboxyl termini. J. Biol. Chem. 267:3257-3261.

Rukkwamsuk, T., T. A. M. Kruip, G. A. L. Meijer, and T. Wensing. 1999a. Hepatic fatty acid composition in periparturient dairy cows with fatty liver induced by intake of a high energy diet in the dry period. J. Dairy Sci. 82:280-287.

Rukkwamsuk, T., T. Wensing, and M. J. H. Geelen. 1998. Effect of overfeeding during the dry period on regulation of adipose tissue metabolism in dairy cows during the periparturient period. J. Dairy Sci. 81:2904-2911.
Rukkwamsuk, T., T. Wensing, and M. J. H. Geelen. 1999b. Effect of fatty liver on hepatic gluconeogenesis in periparturient dairy cows. J. Dairy Sci. 82:500-505.

Schmidt, E., and F. W. Schmidt. 1995. Glutamate Dehydrogenase (EC 1.4.1.3). Pages 216-227 in Methods of Enzymatic Analysis. Vol. 3. Hans Ulrich Bergmeyer, ed. VCH Verlagsgesellschaft mbH, Weinheim, Germany.

Sedlak, T. W., and S. H. Snyder. 2004. Bilirubin benefits: Cellular protection by a biliverdin reductase antioxidant cycle. Pediatrics 113:1776-1782.

Sejersen, H., and S. I. Rattan. 2009. Dicarbonyl-induced accelerated aging in vitro in human skin fibroblasts. Biogerontology 10:203211.

Van den Top, A. M., M. J. Geelen, T. Wensing, G. H. Wentink, A. T. Van 't Klooster, and A. C. Beynen. 1996. Higher postpartum hepatic triacylglycerol concentrations in dairy cows with free rather than restricted access to feed during the dry period are associated with lower activities of hepatic glycerolphosphate acyltransferase. J. Nutr. 126:76-85.

Watford, M. 2003. The urea cycle: Teaching intermediary metabolism in a physiological setting. Biochem. Mol. Biol. Educ. 31:289-297. 